\title{
溶接組立変形シミュレーション一切断から歪取まで一
}

\section{Prediction of Welding Distortion during Assembly Process from Cutting through Straightening}

村川英一・大阪大学接合科学研究所

Hidekazu Murakawa, Joining and Welding Research Institute, Osaka University

Key Words: Welding Distortion, Prediction, Inherent Deformation, Elastic FEM, Cutting, Forming, Straightening

\section{㖮文要旨}

鋼構造物のほとんどは熱切断された部材を溶接により順次組み合わせることにより製作される。したがってこうした溶接構造 物の変形を抑え十分な寸法精度を確保するためには、切断から歪取までの各段階における変形を予測する技術が必要となる。本 研究では、固有ひずみの概念と部材間の結合状態を表現する界面要素を用いた溶接組立変形シミュレーション法を開発した。

\section{1. 緒輍}

船、自動車、車両、橋梁、化学プラント、発電機器など多 くの工業製品は、ガス、アーク、プラズマ、電子ビーム、レ ーザなどの熱源を用いた切断、曲面成形、溶接、歪取という 一連の工程により製作される。一方、熱加工により生じる局 部的な収縮は製品全体の変形の原因となる。このような変形 を事前に予測し、これを低減するための対策を検討するため の道具として著者らは固有ひずみの概念と界面要素を用い た溶接組立変形予測を目的とした有限要素法を開発した。固 有ひずみの概念は固有応力、固有変形および固有力の概念と 密接に関連しており、溶接における固有ひずみで、拘束が小 さい横収縮は変形として現れ拘束が大きい繸収縮は応力あ るいはカとして現れる。このことは固有変形と固有力の両者 を適宜併用するのが自然であることを意味し、この考え方と 界面要素を用いて構築された溶接変形予測法について述べ る。

\section{2. 固有ひずみ、固有応力、固有変形、固有力}

全ひずみ $\varepsilon$ は、弾性ひずみ $\varepsilon^{e}$ 、塑性ひずみ $\varepsilon^{p} 、$ 熱ひず

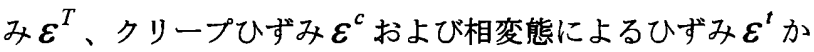
ら構成される。すなわち.

$$
\varepsilon=\varepsilon^{e}+\varepsilon^{p}+\varepsilon^{T}+\varepsilon^{c}+\varepsilon^{t}
$$

ここで、変形および応力はそれぞれ全ひずみ $\varepsilon$ と弾性ひずみ $\varepsilon^{e}$ に対応付けられることから式(1)は次のように書き直すこ とができる。

$$
\varepsilon-\varepsilon^{e}=\varepsilon^{p}+\varepsilon^{T}+\varepsilon^{c}+\varepsilon^{t}=\varepsilon^{*}
$$

式(2)の右辺の非弾性ひずみの和を固有ひずみ $\varepsilon^{*}$ と定義する と、この式は、固有ひずみにより変形と残留応力が作られる ことを示している。さらに、薄板の場合に注目すると、変形 および残留応力は、主として溶接線方向の固有ひずみ $\varepsilon_{x}^{*}$ と溶 接線に垂直方向の固有ひずみ $\varepsilon_{y}^{*} に よ り$ 作られる。

固有ひずみに応カーひずみ関倸を適用すると、形式的に固 有応力 $\sigma_{x}^{*} 、 \sigma_{y}^{*}$ が定義される。

$$
\sigma_{x}^{*}=\frac{E}{1-v^{2}}\left(\varepsilon_{x}^{*}+v \varepsilon_{y}^{*}\right) 、 \sigma_{y}^{*}=\frac{E}{1-v^{2}}\left(v \varepsilon_{x}^{*}+\varepsilon_{y}^{*}\right)
$$

また、固有ひずみを溶接線に垂直な断面について積分し板 厚 $h$ に関する平均をとることで固有変形、すなわち、縦収縮 $\delta_{L}^{*}$ 、横収縮 $\delta_{T}^{*}$ 、縦曲り $\theta_{L}^{*}$ 、横曲り $\theta_{T}^{*}$ が定義される。

$$
\begin{aligned}
& \delta_{L}^{*}=\frac{1}{h} \int \varepsilon_{x}^{*} d x d z 、 \delta_{T}^{*}=\frac{1}{h} \int \varepsilon_{y}^{*} d x d z \text {, } \\
& \theta_{L}^{*}=\frac{1}{I} \int z \varepsilon_{x}^{*} d x d z 、 \theta_{T}^{*}=\frac{1}{I} \int z \varepsilon_{y}^{*} d x d z \\
& \text { ここで、 } I=\frac{1}{12} \int z^{2} d x d z
\end{aligned}
$$

同じ矩形板の収縮を固有ひずみおよびこれと等価な固有変 形で表現したものが図 1、2である。さらに、式(4)で定義さ れた固有変形を力あるいはモーメントに変換することによ り固有力 $F_{L}^{*} 、 F_{T}^{*}$ と固有モーメント $M_{L}^{*} 、 M_{T}^{*}$ が定義される。

$$
\begin{aligned}
& F_{L}^{*}=E \int \varepsilon_{x}^{*} d x d z=E h \delta_{L}^{*} 、 F_{T}^{*}=E \int \varepsilon_{y}^{*} d x d z=E h \delta_{T}^{*} 、 \\
& M_{L}^{*}=E \int z \varepsilon_{x}^{*} d x d z=E I \theta_{L}^{*} 、 M_{T}^{*}=E \int z \varepsilon_{y}^{*} d x d z=E I \theta_{T}^{*}
\end{aligned}
$$

3. 固有ひずみ、固有变形、固有力の有限要素法への茾入 溶接構造物の組立工程は、切断、曲げ加工、溶接、歪取か ら構成され、いずれも熱加工であり、切断、溶接などでは固 有ひずみが線状に集中して分布し、曲げ加工では広範囲に分 布するため、前者は固有変形として、また後者は固有ひずみ として有限要素法に導入することができる。また、拘束が小 さい横収縮は変形として現れ、拘束が大きい縦収縮はほとん どが応力あるいは力（Tendon Force）として表れるので横収 縮および綐収縮に対して固有変形と固有力を図3のように適 宜選択して用いるのが自然である。ここで注意すべき点は、 図 1 あるいは図 2 に示された固有ひずみの䋛収縮成分と等価 な縦収縮を表現するためには、図 3 (b)に示されるように固有 力に加えてポアソン比による横方向への膨張を打消すため の横方向の固有変形を重ね合わせる必要があるという点で ある。溶接線に接した要素に溶接による局部収縮を固有変形 および固有力(Tendon force)の組合せとして導入する方法を より具体的に示したものが図 5 である。

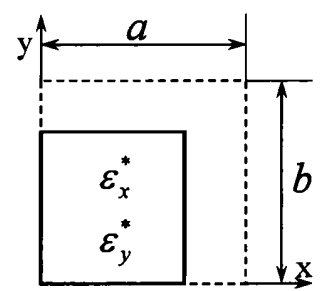

(welding direction)

図 1 固有ひずみを用いた収縮の 収縮の表現。

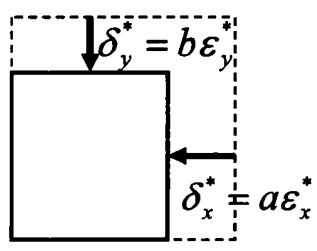

図 2 固有変形を用いた 収縮の表現 
このように固有ひずみ、固有変形、固有力をそれぞれの特 徴を活かして適宜選択的に用いることにより、効率的な FEM 計算手法が構築できる。

\section{4. 切断、接合、ギャップ、ズレの表現}

溶接構造物の組立変形は熱による局部収樎が主たる原因 の一つであるが、部材を順次組付けて行く際に生じる部材間 のギャップやズレも重要な要因である。提案手法ではギャッ プやズレを表現するとともに、部材間の切断・接合を表現す るために部材間に図 5 に示される非線形バネである界面要 素を導入した。また、界面要素の特性は図 6 に示されるよう に、剛性 $K$ 、結合強度 $f_{\max }$ 、ギャップ $u_{G}$ をパラメータと して表すことができる。

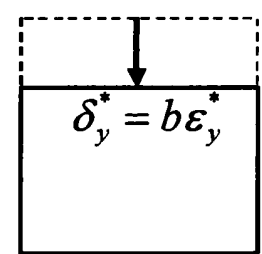

(a) 横収縮

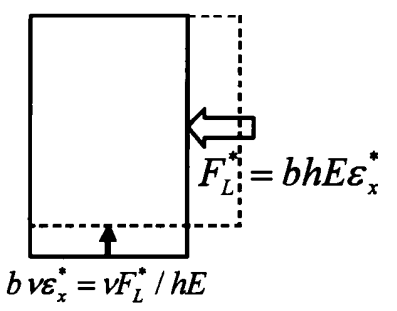

(b) 縦収縮
図 3 固有変形と固有力を用いた収縮の表現

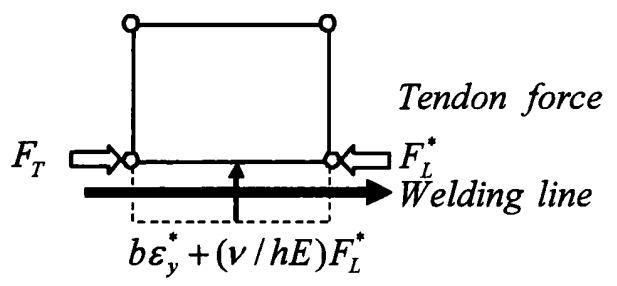

Transverse shrinkage

図 4 要素における固有変形および固有力

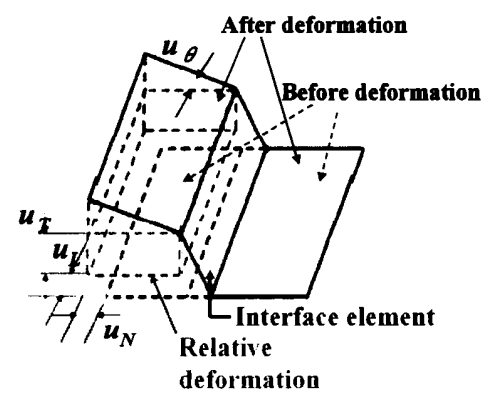

図 5 界面要素および界面における相対変位の定義.
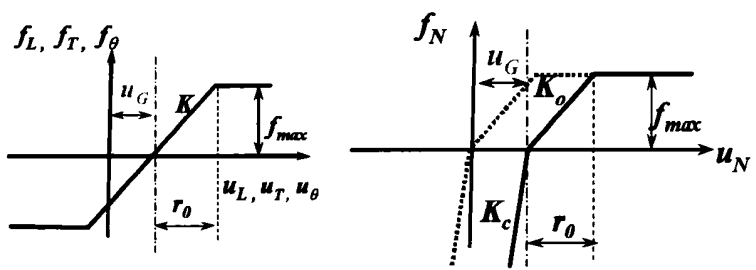

図 6 部材間の結合関俰を表現する界面要素の特性

\section{5. 切断から歪取までの一而解析}

著者らが提案する有限要素法は溶接や線状加熱などの熱 加工による局部収縮を固有変形や固有力で表現し、部材間の 切断・接合を界面要素により表現しているため、図 7 に示さ れるように熱切断から歪取までの全溶接組立工程を一貫解 析することができる。

\section{6. 船のブロック搭域による維曲り变形の予湨}

ブロック工法により建造される船は、ブロックを順次搭载 するため結果的に船首尾が反り上がるように変形する。これ を具体的に示したものが図 8 であり、最終的に $30 \mathrm{~mm}$ 程度 の変形が生じる。このような繸曲り変形は、ブロックを搭載 して行く過程で生じるブロック間のずれやギャップが累積 し生じるものであり、界面要素を用いることによりこれを考 㦄した変形予測が可能となる。

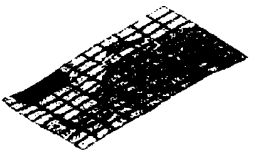

(1) cutting

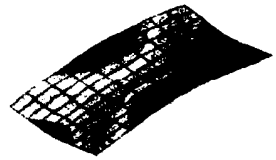

(2) forming

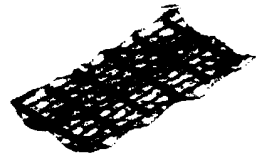

(3) fitting

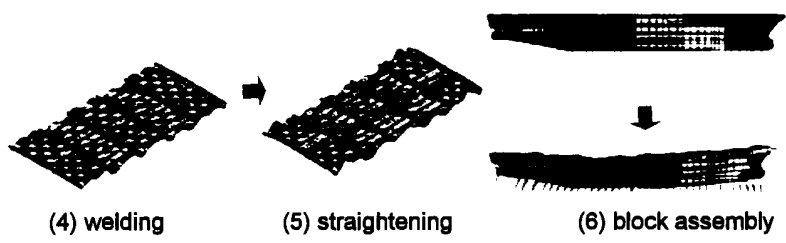

図 7 切断から昰取までの一开解析

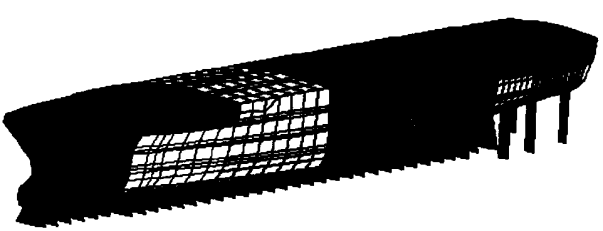

(a) ブロック分割図

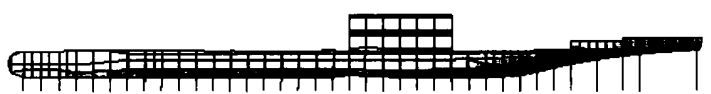

(b) ブロック搭載の初期段階

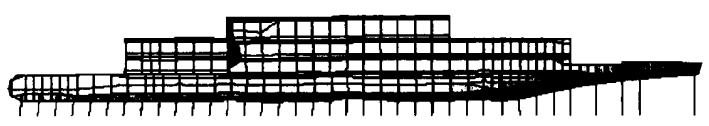

(c) ブロック搭載の中間段階

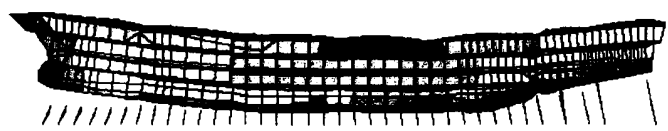

(d) ブロック搭載完了時

図 8 ブロック搭載による縦曲り変形の予測 